PRÁVNE ROZPRAVY ON-SCREEN III. - Sekcia verejného práva

online vedecká konferencia - 7. máj 2021

\title{
A CRITICAL EXAMINATION OF CHINESE LIABILITY LIMITATION RULE FOR THE SEA PASSENGER'S INJURY COMPENSATION Wei Xiao ${ }^{1}$ \\ https://doi.org/10.24040/pros.07.05.2021.svp.308-316
}

\begin{abstract}
Liability limitation is a very important defense of the carrier by sea, which means the carrier could claim a limitation once the passenger alleged for compensation for his personal injury or death. China has a dual-orbit Liability Limitation system differentiating international and domestic carriage of passengers by sea, which results a big gap between the two types. This legislation mode is faced with challenges in recent years. Firstly, with the development of Chinese economy and the rising of Average National GDP, the domestic compensation limitation is sharply out-dated. In judicial practice, the judges had difficulties in application of these out-dated rules; secondly, the traditional international rule of Athens Convention has been revised by the newest protocol 2002. It is time that China should abolish the old rules and revise Chinese Maritime Code to match Chinese current needs and meanwhile to keep up with the developing trend of international rules, namely, the 2002 Amendment of Athens Convention.
\end{abstract}

\section{Key words}

Carriage of Passengers by sea, Sea Passengers, Personal Injury Compensation, Limitation of Liability

\section{Introduction}

The sea passenger's injury compensation is a branch issue of Chinese personal injury compensation system. Generally speaking, with the development of Chinese economy in recent years, the National GDP of China is improving very fast, and correspondingly, the CPI (consumption price index) is also rising very quickly. In recent ten years, in judicial practice, the personal injury compensation amount has been increased dramatically. In contrast, the sea passenger's injury compensation amount was too low and not rationale. The reason is that the rules for the sea passenger's compensation were outdated, for they have been kept unchanged for almost 30 years. Chinese Maritime Code came into being in 1993, and the PRC Ministry of Transport (MOT) also enacted some regulations concerning the personal injury compensation

\footnotetext{
${ }^{1}$ The Author is Associate professor and postgraduate supervisor in the Nanjing Normal University Law School, Researcher of "Think tank of China Institute of Law modernization", council member of the Chinese Society of International Economic Law (CSIEL), and the counselor of Jiangsu Maritime law Society.
} 


\section{PRÁVNE ROZPRAVY ON-SCREEN III. - Sekcia verejného práva}

online vedecká konferencia - 7. máj 2021

on the sea. These rules kept unchanged in the following three decades, which resulted confusions and uncertainties in Chinese Judicial Practice.

\section{Chinese Law Regime of Sea Passenger's Injury Compensation}

\subsection{Athens Convention}

Athens Convention 1974 is the first Convention regulating the contractual relationships between the sea carriers and passengers, which deems to achieve a balance of interests between sea carriers and passengers in the risky sea transportation. ${ }^{2}$ The purpose of this convention is two-folded: firstly, it establishes a liability regime of recovery of damages arising from death and personal injury of the passengers carried on a seagoing vessel; on the other hand, this convention also allows the carriers defend the claims of passengers and limit their liabilities to a certain amount.

In 1980s, China began to carry out opening- up policies and was eager to participate in the world trade and commerce. As China has a total length of coastline of 32000 kilometers, including the coastline of 18000 kilometers and the island coastline of 14000 kilometers, it has a potential of developing international carriage of goods and passengers by sea. In such a background, the Athens Convention 1974 was ratified in $8^{\text {th }}$ Meeting of the Standing Committee of the Sixth Session National People's Congress, and came into effect on 30 August 1994.

\subsection{PRC Maritime Code}

Maritime Code of the People's Republic of China (PRC Maritime Code), which is the first legislation in maritime after the foundation of People's Republic of China (PRC), was adopted at the $28^{\text {th }}$ Meeting of the Standing Committee of the Seventh National People's Congress on November $7^{\text {th }}, 1992$, and entered into force on July $1^{\text {st }} 1993$. In the process of drafting, the legislators incorporated the most important rules of Athens Convention 1974 into

\footnotetext{
${ }^{2}$ As of 24 November 2020, the number of contracting states is 25. Website of International Maritime Organization, "Status of Conventions - Comprehensive information including Signatories, Contracting States, declarations, reservations, objections and amendments", p342, see: https://www.imo.org/en/About/Conventions/ Pages/StatusOfConventions.aspx.
} 


\section{PRÁVNE ROZPRAVY ON-SCREEN III. - Sekcia verejného práva}

online vedecká konferencia - 7. máj 2021

it, including the definitions, Basis of liability, limit of liabilities, loss of the rights to claim for limitations, etc. However, we must recognize that limited by the length of the code, only a substantial part of Athens Convention articles were not incorporated into Chinese Maritime Code (Chapter Five), which made it incomplete for regulating.

\section{Main Rules Stipulated by the PRC Maritime Code ${ }^{3}$}

\subsection{Basis of Liability \& Burden of Proof}

\subsubsection{Shipping Incidents}

PRC Maritime Code Article 114.3 provides: "If the death of or personal injury to the passengers or loss of or damage to the passengers' cabin luggage occurred as a result of shipwreck, collision, stranding, explosion, fire or the defect of the ship, it shall be presumed that the carrier or his servant or agent has committed a fault, unless proof to the contrary has been given by the carrier or his servant or agent."

Interpretation: If a shipping incident occurred in the carriage by sea, unless the carrier could convince the judge otherwise, the carrier is presumed to be faulty and is obliged to compensate the damages of personal injury or death of the passengers arising therefrom.

\subsubsection{Non-shipping Incidents}

PRC Maritime Code Article 114 provides: "During the period of carriage of the passengers and their luggage as provided for in Article 111 of this Code, the carrier shall be liable for the death of or personal injury to passengers or the loss of or damage to their luggage resulting from accidents caused by the fault of the carrier or his servant or agent committed within the scope of his employment or agency.

The claimant shall bear the burden of proof regarding the fault of the carrier or his servant or agent, with the exception, however, of the circumstances specified in paragraphs 3 and 4 of this Article."

\footnotetext{
${ }^{3}$ PRC Maritime Code Chapter Five "Contract of Carriage of Passengers by Sea” includes 19 articles in total.
} 


\section{PRÁVNE ROZPRAVY ON-SCREEN III. - Sekcia verejného práva}

online vedecká konferencia - 7. máj 2021

Interpretation: if passengers' personal injury is resulted from an incident other than shipping incidents, the carrier will be held liable only if the claimant could convince the judge that the carrier has done something faulty intentionally or negligently.

\subsubsection{Exemption or Mitigation of the Carrier's Liability}

PRC Maritime Code Article 115 Provides: "If it is proved by the carrier that the death of or personal injury to the passenger or the loss of or damage to his luggage was caused by the fault of the passenger himself or the faults of the carrier and the passenger combined, the carrier's liability may be exonerated or appropriately mitigated.

If it is proved by the carrier that the death of or personal injury to the passenger or the loss of or damage to the passenger's luggage was intentionally caused by the passenger himself, or the death or personal injury was due to the health condition of his, the carrier shall not be held liable."

Interpretations: in case the passengers' injury was caused by himself or third parties (not stated in the article), or caused jointly by the carrier and himself, the carrier will not be held liable or his liability is to be reduced.

\subsection{The Amount of Liability Limitation}

Article 117 of PRC Maritime Code provides: "Except the circumstances specified in paragraph 4 of this Article, the limitation of liability of the carrier under each carriage of passengers by sea shall be governed by the following: (1) For death of or personal injury to the passenger: not exceeding 46,666 SDR (Special Drawing Rights) per passenger”, and afterwards provides in the same Article: "The limitation of liability of the carrier with respect to the carriage of passengers by sea between the ports of the People's Republic of China shall be fixed by the competent authorities of transport and communications under the State Council and implemented after its being submitted to and approved by the State Council.”

From above, we can see that China has a Two-layer rule for the Sea passengers' injury compensation. Firstly, the compensation for the international sea passengers would be subject to the liability limitation rules stipulated in PRC Maritime Code (International means that the journey includes at least one oversea port, for example, a journey from Shanghai port to a Japan 


\section{PRÁVNE ROZPRAVY ON-SCREEN III. - Sekcia verejného práva}

online vedecká konferencia - 7. máj 2021

seaport is an international trip); secondly, the compensation for the domestic sea passengers (a journey from Shanghai to another Chinese seaport is a domestic one)would be subject to the Rules promulgated by PRC Ministry of Transportation. As a result, there exists a big gap between the two different types of journeys.

\subsection{The Loss of Rights to claim Limitation of Liabilities}

PRC Maritime Code Article 118 stipulates that: "If it is proved that the death of or personal injury to the passenger ..... resulted from an act or omission of the carrier done intentionally or recklessly with knowledge that such death or personal injury or such loss or damage would probably result, the carrier shall not invoke the provisions regarding the limitation of liability contained in Articles 116 and 117 of this Code."

\section{Regulations Promulgated by other State Organs}

\subsection{The Regulations Promulgated by PRC Ministry of Transport}

"Provisions of the People's Republic of China on the Limitation of Liability for Carriage of Passengers by Sea between Chinese Ports", which was promulgated in 1993 and came into effect in 1994 was made by the State Council according to Article 117, and 211 of Maritime Code. Article 2 states: "These provisions shall apply to the carriage of passengers by sea between the ports of the People's Republic of China". Article 3.1 states: "The limitation of liability of the carrier in each carriage of passengers by sea shall be governed by the following provisions: In case of personal injury or death of a passenger, each passenger shall not exceed RMB 40,000.”

\subsection{The Regulations Promulgated by PRC Supreme Court}

PRC Supreme Court issued "Specific Provisions of the Supreme People's Court on Compensation for Damages in Cases of Personal Injury or Death at Sea involving Foreign Elements" ${ }^{\text {in }}$ 1991, in order to establish a standard of compensation in all kinds of maritime

\footnotetext{
${ }^{4}$ Website of the PRC Maritime Academy, see: http:// www. cmla.org.cn.
} 


\section{PRÁVNE ROZPRAVY ON-SCREEN III. - Sekcia verejného práva}

online vedecká konferencia - 7. máj 2021

activities involving international elements. Article 1 interprets what is international, stating that "The term 'compensation cases for damage to persons injured or injured at sea involving foreign elements'refers to maritime compensation cases arising out of the course of operations at sea (including sea waters open to sea) or in ports, in which the subject and object of the case, or the legal facts have foreign elements. The disabled person and the surviving family of the deceased have the right to file a lawsuit with the competent maritime court in accordance with the law to request the infringer to compensate for the loss." Article 7 provides the amount of liability limitation: "The maximum amount of compensation for loss of life or injury at sea is RMB 800,000 per person."

\section{A Typical Case of Cruise Passenger's Personal Injury Compensation: Miss Yang v Carnival PLC ${ }^{5}$}

\subsection{Backgrounds of the Case}

Carriage of passengers by sea was not a main form of transportation in China in the past few decades, as a result, not as much attention was paid to this field as to the carriage of goods by sea for a considerable period of time. However, in recent ten years, with the emergence and popularity of a new type of consumption for holiday, namely, the Cruise travel became popular in China, more and more people chose Cruise travel as their way of amusement. After the first foreign cruise ship began to operate in China in 2006, several world top cruise companies were attracted by Chinese market, either establishing branches in China or chartering their cruise ships or made other contract arrangements with Chinese tour operators to gain their profits. Not until the COVID-19 broke out worldwide in 2020, the number of the people engaging in Cruise travel kept rising. Correspondingly, a number of personal injury and death compensation disputes arose and the injured party brought the case to Chinese maritime courts. If we search the "PRC Website of Contexts of Judgments and Verdicts"with "compensation of injury and death of Cruise passengers", we can get more than 20 cases (2014- 2020). ${ }^{6}$

\footnotetext{
${ }^{5}$ No 2336 Civil Judgment (2016) by Shanghai Maritime Court.

${ }^{6}$ Website of PRC Contexts of Judgments and Verdicts, see: http://www. court.gov.cn.
} 


\section{PRÁVNE ROZPRAVY ON-SCREEN III. - Sekcia verejného práva}

online vedecká konferencia - 7. máj 2021

\subsection{Facts of the Case}

The plaintiff Miss Yang, who is seven years old, got on board of the Cruise ship named "Blue Diamond Princess"with her mother in Shanghai port and began their trip to Europe. The Cruise ship was under the operation and management of the Carnival PLC Company. During the trip, the plaintiff was drowned to unconsciousness in the swimming pool on the deck, and severely injured by her brain, disabled in the rest of her life. The plaintiff's mother brought a suit against the carrier, alleging that the defendant failed to provide a safe consuming place, for there was no any warning of the depth of the swimming pool and no any lifeguard besides to watch out, as a result, the defendant shall take all liability to compensate the losses on the part of the plaintiff arising out of the severe injury.

\subsection{Focus of the Case: Liability Limitation of the Carrier}

In the court examination, the plaintiff's lawyer argued that the defendant shall lose the right to claim for liability limitation. He argued that the plaintiff's injury would not happen if the defendant had paid due diligence and attention to secure the safety of cruise ship facilities. The lawyer found out a newspaper published in a European country, on which a similar drowning incident in the same swimming pool was reported. However, the defendant did not take any measures to improve the safety conditions of the swimming pool. Consequently, the defendant had no right to claim for liability limitations. Hence, according to PRC Maritime Code Article 118, the defendant had ignored the potential danger recklessly and shall lose the right to claim liability limitation.

Based on the examination, the judge supported the plaintiff's allegations and finally made a judgment for the plaintiff, and the defendant shall be bound to pay the actual losses arising out of the plaintiff's personal injury, totally amounting to 3930,000 RMB.

\section{The Dawn of Revision: Developing Trend of Chinese Maritime Code on the Rules of} Liability Limitation

Since the PRC Maritime Code came into effect in 1993, the situation has changed greatly, however, the law kept unchanged. The inadequacy of the PRC Maritime Code has 


\section{PRÁVNE ROZPRAVY ON-SCREEN III. - Sekcia verejného práva}

online vedecká konferencia - 7. máj 2021

raised confusions and uncertainties in the maritime judicial practice. Hence, China began to take steps to revise the Maritime Code, and the current final draft was made in $2018 .^{7}$

\subsection{Improving the Amount of Liability limitation}

The latest amendment of 1974 Athens Convention in 2002 improved the liability limitation to 250,000 SDR. Considering both this development and the changed situation of China, the legislators improved the liability limitations up to 250,000 SDR in Article 117 of the new Draft, providing: "The limitation of liability of the carrier under each carriage of passengers by sea shall be governed by the following: (1) For death of or personal injury to the passenger: not exceeding 250,000 SDR per passenger."

\subsection{Eliminating the gap between international and domestic sea passengers}

In 1990s, China was in a preliminary stage of economic development and Chinese National GDP was much lower compared with US and EU countries. Hence, the first PRC Maritime Code established a dual- layer rule for the compensations for the international and domestic sea passengers. However, with the rising of the people's income and living standard, the dual- layer rule is out- dated and has resulted unfairness in the judicial practice. Consequently, Article 117 of the new Draft eliminates the difference of liability limitation between the international and domestic sea passengers.

\subsection{Distinguishing the shipping and Non-shipping incidents}

In the 2002 Amendment of the Athens Convention, a very important development is that the liability limitation will be only applied to shipping incidents. In contrast, the current PRC Maritime Code did not make such a difference. In Chinese judicial practice, liability limitation could be applied to the compensation claims arising out of both shipping incidents and non-shipping incidents. As far as the non-shipping incidents are concerned, they had no

\footnotetext{
${ }^{7}$ Ministry of Transport: Notice of Collecting public opinions on the revision of "PRC Maritime Code" Government Information publication-MOT (mot.gov.cn).
} 


\section{PRÁVNE ROZPRAVY ON-SCREEN III. - Sekcia verejného práva}

online vedecká konferencia-7. máj 2021

any difference in nature with those injuries occurred on land, so it is much more rationale to adopt the new rule of 2002 Amendment.

\section{(․) 10}

Obsah článku podlieha licencii Creative Commons Attribution 4.0 International Licence CC BY (Wei Xiao). 